\author{
Marcin Kosman \\ Uniwersytet Jagielloński \\ marcin.j.kosman@gmail.com
}

\title{
„Toto, we are in the Soviet Union”. Jaka Kraina Oz istnieje w Związku Radzieckim?
}

\author{
„Toto, We Are in the Soviet Union”. What Kind of World of Oz Is There?
}

\begin{abstract}
The essay compares Alexander Volkov's Wizard of the Emerald City with L. Frank Baum's Wonderful Wizard of $\mathrm{Oz}$ as regards the differences conditioned culturally and those determined by the diverse stylistic dominants. Being an adaptation of Baum's book, Volkov's novel contains certain elements characteristic of the Soviet socialist realist writing, but also numerous allusions to Russian folklore. The author of the essay discusses the changes introduced in the translation and provides a psychological and cultural justification.
\end{abstract}

Keywords: Russian literature, Alexander Volkov, L. Frank Baum, children's literature, American literature, dominant, culturally charged elements in translation

Streszczenie: W szkicu powieść Czarodziej Szmaragdowego Miasta Aleksandra Wołkowa zostaje porównana z Czarnoksiężnikiem z Krainy $O z$ L. Franka Bauma pod względem różnic zarówno warunkowanych kulturowo, jak i wynikających z odmiennych dominant stylistycznych. Książka Wołkowa, będąca adaptacją dzieła Bauma, zawiera pewne elementy typowe dla radzieckiej powieści socrealistycznej, przy czym tłumacz uwzględnił w niej również liczne aluzje do rosyjskiego folkloru. Autor omawia zmiany dokonane w przekładzie oraz ukazuje ich uzasadnienie z perspektywy psychologicznej i kulturowej.

Słowa kluczowe: literatura rosyjska, Aleksander Wołkow, L. Frank Baum, literatura dziecięca, literatura amerykańska, dominanta, elementy nacechowane kulturowo w przekładzie

W roku 1900 Lyman Frank Baum napisał książkę, która od razu stała się częścią kanonu literatury dziecięcej: Czarnoksiężnika z krainy $O z$. Powieść zdobyła wielką popularność, mimo iż dla samego autora tak duży sukces dzieła był zaskoczeniem $^{1}$. Po dziś dzień jednak historia Dorothy Gale, jej psa Toto oraz

${ }^{1}$ E. Haber, Is Magic Land Oz? A.M. Volkov and the Question of Originality, „Detskiechtenija” 2014, nr 6 (2), s. 255. 
trójki niezwykłych przyjaciół - Żelaznego Drwala, Tchórzliwego Lwa i Stracha na Wróble - zdobywa nowe rzesze wiernych czytelników, o czym świadczą liczne adaptacje filmowe, sceniczne czy książkowe.

Szczególnie ciekawą wariacją na temat książki Bauma jest napisany przez radzieckiego profesora matematyki Aleksandra Wołkowa Czarodziej Szmaragdowego Miasta (ros. Волшебник Изумрудного города). Wołkow ukończył pierwszą wersję przekładu w 1939 roku, zaledwie pięć lat po tym, jak Maksym Gorki proklamował socrealizm na Zjeździe Pisarzy Radzieckich w Moskwie.

Na początku lat dwudziestych XX wieku bajka nie była gatunkiem mile widzianym w Związku Radzieckim. Marina Balina pisze, iż w roku 1921 w całym kraju opublikowano jedynie trzydzieści trzy książki dla dzieci². Nadieżda Krupska nazwała twórczość Kornieja Czukowskiego „burżuazyjną mrzonką”, a pozycje wielu innych twórców literatury dziecięcej (między innymi Aleksandra Afansajewa, Siergieja Aksakowa czy Olgi Rogowej) usuwano z bibliotek $^{3}$. Siłę bajki jako narzędzia pomocnego w wychowaniu nowego człowieka dostrzeżono dopiero w połowie dekady, dzięki czemu tacy autorzy, jak Samuił Marszak czy Borys Żytkow, stali się znaczącymi postaciami w świecie literackim swoich czasów. Władza dbała jednak o to, aby umysły radzieckich czytelników nie były zmącone przez wpływy Zachodu, wobec tego utwory zagranicznych autorów były odpowiednio przeredagowywane, aby mogły się wpasować w klucz bieżącej ideologii partyjnej oraz potrzeby proletariackiej publiki ${ }^{4}$. Wspomniany wyżej Marszak, tłumacząc poezję Roberta Burnsa, usunął z niej wszystkie odniesienia do Boga i religii, a także do minimum ograniczył wyrażenia charakterystyczne dla szkockiego dialektu ${ }^{5}$. W latach trzydziestych w ZSRR zaczęły się również pojawiać trawestacje klasycznych utworów dla dzieci. Za przykład mogą tu służyć adaptacja Pinokia Carla Collodiego Ztoty kluczyk, albo przygody Buratino Aleksieja Tołstoja oraz wariacja na temat Doktora Dolittle Hugha Loftinga - Doktor Ajbolit Kornieja Czukowskiego (w Polsce pozycja ta znana jest pod tytułem Doktor Ojboli). Teksty tego typu, jak zresztą ich pierwowzory, uczyły dzieci, czym jest dobro i zło, oraz miały wydźwięk dydaktyczny; realia zostały jednak odpowiednio zmodyfikowane. $\mathrm{Na}$ przykład w adaptacji Tołstoja postać właściciela teatru lalek Karabasa Barabasa (wzorowanego na Połykaczu Ognia) zostaje wyeksponowana i przypisano mu cechy bezdusznego kapitalisty, który wyzyskuje słabszych od siebie ${ }^{6}$.

${ }^{2}$ M. Balina, Creativity through Restraint: The Beginnings of Soviet Children's Literature [w:] Russian Children's Literature and Culture, red. M. Balina, L. Rudova, New York 2008, s. 7.

3 Tamże, s. 8.

${ }^{4}$ N. Vid, Use of Domesticated and Foreignized Method in the Soviet School of Translation, „ELOPE” 2007, t. 4, nr 1-2, (red. S. Komar, U. Mozetic), s. 153.

${ }_{5}$ Taż, Teaching Russian through Translations, „Informatologia” 2014, t. 47, nr 1, s. 54.

${ }^{6}$ R. Branson, Carving the Perfect Citizen: The Adventures of Italian Pinocchio in the Soviet Union and the United States, „Honors Projects” 2014, s. 18, http://digitalcommons.iwu.edu/ cgi/viewcontent.cgi?article=1017\&context=intstu_honproj, dostęp: 15.08.2017. 
Przez wspólne pokonanie tyranii Barabasa bohaterowie odnoszą moralne zwycięstwo, dzięki któremu przekonują się o zaletach kolektywu i wyższości działań wspólnotowych nad postawami indywidualistycznymi ${ }^{7}$.

Czarodziej Szmaragdowego Miasta różni się znacznie od amerykańskiego oryginału. Przekład Aleksandra Wołkowa obfituje w treści, z którymi radziecki czytelnik w latach pięćdziesiątych mógł się identyfikować dużo bardziej niż amerykański. Mowa tutaj o elementach obecnych w twórczości ludowej oraz bajkach nawiązujących do tradycji folklorystycznej. Jednocześnie Czarodziej Szmaragdowego Miasta zawiera również pewne cechy powieści socrealistycznej. W wielu miejscach została też gruntownie zmieniona warstwa syntaktyczno-morfologiczna tekstu. Wydaje się zatem, że tłumaczenie Wołkowa jest $\mathrm{w}$ istocie adaptacją, pozbywa się części elementów charakterystycznych dla amerykańskiej kultury i substytuuje je ekwiwalentami zrozumiałymi dla przedstawiciela kultury docelowej ${ }^{8}$. Warwara Krasilnikova twierdzi wprost, że należy nazywać $C z a r o d z i e j a \ldots$ nową wersją starej opowieści, gdyż grunt społeczno-kulturowy, na którym pierwotnie operował Baum, został zaadaptowany w zauważalnym stopniu'. Aleksander Wołkow naniósł w swoim przekładzie wiele zmian w stosunku do tekstu Bauma. Typologicznie można podzielić je na następujące kategorie: nazewnictwo, zmiany treści oraz dodawanie nowych rozdziałów.

Poważne korekty zaszły w imionach bohaterów. Główna bohaterka, Dorothy Gale, w wersji radzieckiej nazywa się Элли Смит (ang. Elli Smith). Nie są znane powody, dla których Wołkow zdecydował się na taką ingerencję. Można jednak domniemywać, że dla rosyjskojęzycznego odbiorcy nazwisko Gale (transliterowane jako Гейл) mogło się wydawać trudne do wymówienia, toteż zdecydowały tutaj względy fonetyczne. Imię Elli również jest bardziej dźwięczne dla osoby, której ojczystym językiem jest rosyjski. W przypadku imienia protagonistki dochodzić może jeszcze aspekt konotacyjny (Дороти Дуроти - Дура; дурак - głupek lub dureń). Uzasadnienie dla przemianowania Cynowego Drwala (ang. Tin Woodman) na Żelaznego (ros. Железный Дровосек) również wydaje się zakorzenione w sowieckiej tradycji poetyzacji pracy. Żelazo jest materiałem dużo twardszym od cyny, a akcja wielu powieści produkcyjnych rozgrywała się właśnie w hutach czy kopalniach ${ }^{10}$, toteż żelazo wydało się wyborem mocniej oddziałującym na wyobraźnię radzieckiego odbiorcy. Warto odnotować, iż przymiotnik „żelazny” w latach dwudziestych i trzydziestych miał bardzo pozytywne konotacje. Wystarczy tu wspomnieć

7 Tamże, s. 20.

${ }^{8}$ M. Baker, G. Saldanha, Routledge Encyclopedia of Translation Studies: Second Edition, London 2009, s. 3.

9 W.P. Krasilnikova, Psicholingwisticzeskij analiz siemanticzeskich transformacyj pri pieriewodie i litieraturnom pierieskazie chudożestwiennogo tieksta, http://individual.utoronto.ca/psyling/library/tran/krasil_avtoreferat.htm, dostęp: 31.03.2017.

10 Z. Jarosiński, Literatura lat 1945-1975, Warszawa 1996, s. 50. 
choćby pionierską dla socrealizmu powieść Aleksandra Serafimowicza Żelazny potok, w której opisane są bohaterskie działania rewolucjonistów podczas wojny domowej ${ }^{11}$. Co więcej, slogany bolszewików propagujących znaczenie rewolucji nazywano „żelaznymi hasłami” ${ }^{22}$. Strach na wróble (ang. Scarecrow) nie został z kolei przetłumaczony przy użyciu słowa określającego w języku rosyjskim kukłę odstraszającą ptactwo (ros. „пугало”). Wołkow nazwał swojego bohatera imieniem Страшила, które pochodzi od słowa „страшить” (straszyć, wywoływać lęk). Imię Stracha w sowieckiej wersji można tym samym tłumaczyć jako Straszydło. Postać Wołkowa odznacza się jednak podobnym charakterem jak bohater pierwowzoru: nie wzbudza strachu nawet u ptaków, nazwa straszydło jest zatem ironiczna, tak jak w wypadku amerykańskiej wersji. Tytułowy Czarnoksiężnik przybrał imię Goodwin (ros. „Гудвин”). Nie może to dziwić, gdyż nawet Kraina Oz przestała istnieć w pierwotnym kształcie. W wersji Wołkowa jest to Szmaragdowe Miasto. Wart uwagi jest również fakt, że tytułowy $\mathrm{Oz}$, przebywając jeszcze w Stanach, parał się brzuchomówstwem, a Goodwin wykonywał różne zawody, był na przykład lotnikiem. Różnice wynikają z pewnością z warunków kulturowo-społecznych, w jakich żyli obaj autorzy. Frank Baum sam trudnił się aktorstwem, występował w przedstawieniach pod pseudonimem artystycznym Louis F. Baum ${ }^{13}$. Wołkow pozostaje zaś wierny socrealistycznej tradycji stawiania lotników na piedestale, gdyż piloci byli traktowani w tamtych czasach ze szczególną estymą. Nie tylko cieszyli się oni wysokim prestiżem społecznym, lecz byli wręcz uważani za przykładnych synów nowego narodu ${ }^{14}$.

Wadim Baranow zwraca uwagę na rolę kolektywu, stosunek do niego był najważniejszy w charakterystyce człowieka epoki realizmu socjalistyczne$\mathrm{go}^{15}$. Odniesienia do wyższości pracy zespołowej nad działaniem na własną rękę Aleksander Wołkow przemyca już w pierwszym rozdziale. W oryginale Dorothy ukrywa się wraz z rodziną w schronie. Nie ma jednak wzmianki o tym, co wszyscy robią po uderzeniu wiatru. U Wołkowa cała rodzina mieszka w furgonie, wobec czego gdy huragan przewraca skromny domek rodziny Smithów, John podnosi go i naprawia szkody, a Elli pomaga mu, zbierając porozrzucane przez żywioł talerze i kubki, co sprawia, że wszystko jest w porządku aż do czasu następnego huraganu ${ }^{16}$. Ta różnica wynika też po części z tego,

${ }^{11}$ J. Litwinow, Wczesna rosyjska proza radziecka i Rewolucja Październikowa, „Studia Rossica Posnaniensia” 1979, t. 11, s. 32.

12 Tamże, s. 28.

13 K. Rogers, L. Frank Baum, Creator of Oz: A Biography, New York 2002, s. 12-13.

${ }^{14}$ K. Clark, The Soviet Novel: History as Ritual, Chicago 1985, s. 125.

15 W. Baranow, Orudije poznanija i bor'by. O socyalisticzeskom realizmie kak mietodie chudożestwiennogo myszlenija, Moskwa 1978, s. 104.

16 A. Wołkow, Wotszebnik Izumrudnogo goroda, Moskwa 1939, s. 3. O ile nie zaznaczono inaczej, cytaty pochodzą z tego wydania książki. Tłumaczenia cytatów z języka rosyjskiego na polski pochodzą od autora artykułu. 
że portret rodziny u L. Franka Bauma także znacząco odbiega od przedstawienia państwa Smith. Dorothy to sierota mieszkająca z ciotką i wujem. Ciotka Em opisana jest jako niegdyś młoda i piękna kobieta, której cera wraz z upływem czasu stała się ziemista. Wuj Henry z kolei całe dnie spędzał na pracy w polu: „nie wiedział nawet, co to jest radośc” ${ }^{17}$. Chociaż u Wołkowa rodzina głównej bohaterki również ciężko pracuje na roli, stosunek dziewczynki do jej milieu jest u Wołkowa zgoła odmienny. Nie bez znaczenia jest tu kontrastujące otoczenie Dorothy i Elli:

When Dorothy stood in the doorway and looked around, she could see nothing but the great gray prairie on every side. Not a tree nor a house broke the broad sweep of flat country that reached to the edge of the sky in all directions. The sun had baked the plowed land into a gray mass, with little cracks running through it. Even the grass was not green, for the sun had burned the tops of the long blades until they were the same gray color to be seen everywhere. Once the house had been painted, but the sun blistered the paint and the rains washed it away, and now the house was as dull and gray as everything els $\mathrm{e}^{18}$.

W odróżnieniu od swojego amerykańskiego odpowiednika Elli nie może narzekać na brak rozrywek. Towarzystwa dotrzymują jej nie tylko wierny pies Totoszka (Wołkow dodał sufiks -шка do imienia Toto), ale także wujek John, który uczył dziewczynkę czytać i pisać ${ }^{19}$. W późniejszych wydaniach Czarnoksiężnika... Elli przestaje być sierotą; John i Anna stają się rodzicami dziewczynki, pojawiają się też dziadek Rolf i kuzyni, Bob i Dick:

Когда Элли становилось скучно, она звала веселого песика Тотошку и отправлялась навестить Дика и Боба или шла к дедушке Рольфу, от которого никогда не возвращалась без самодельной игрушки ${ }^{20}$.

Z kolei Totoszka - w odróżnieniu od swojego pierwowzoru, Toto - w wersji Wołkowa z chwilą przenosin z Elli do magicznej krainy otrzymał zdolność mówienia. Autor tłumaczy tę zmianę następująco:

17 F.L. Baum, Czarodziej z Krainy Oz, tłum. M. Pawlik-Leniarska, Warszawa 1993, s. 7. W Polsce powieść Bauma doczekała się kilku przekładów. Należy tu również wspomnieć o tłumaczeniach Stefanii Wortman (Czarnoksięznik ze Szmaragdowego Grodu, Warszawa 1962) oraz Pawła Łopatki (Czarnoksiężnik z krainy Oz, Kraków 2000). W artykule odnoszę się jednak do The Wizard of $O z$, żeby zaakcentować różnice między oryginałem a przekładem rosyjskojęzycznym.

${ }_{18}$ F.L. Baum, The Wizard of $O z$, London 1993, s. 7-8.

19 A. Wołkow, Wotszebnik Izumrudnogo goroda, dz. cyt., s. 4.

20 Tenże, Wotszebnik Izumrudnogo goroda, Moskwa 1963, s. 6. „Gdy Elli zaczynała się nudzić, dziewczynka wołała swojego pieska o imieniu Totoszka i wybierała się odwiedzić Dicka i Boba albo dziadka Rolfa, od którego zawsze wracała z ręcznie robioną zabawką”. 
У американского писателя Тотошка - немой. Но мне казалось, что в волшебной стране, где разговаривают не только птицы и звери, но даже люди из железа и соломы, умный и верный Тотошка тоже должен говорить и он у меня заговорил ${ }^{21}$.

Dla Wołkowa obdarowanie wiernego towarzysza protagonistki umiejętnością mowy było czymś oczywistym i niewymagającym głębszego uzasadnienia. Wydaje się, że Totoszka może być przykładem magicznego pomocnika, o którym Władimir Propp pisze w Morfologii bajki. Według badacza mówiący pies to tak zwany częściowy pomocnik, który wprawdzie stoi w hierarchii niżej od konia, ale wciąż może wspierać bohatera na wielu płaszczyznach ${ }^{22}$. Jest to postać charakterystyczna dla wschodniosłowiańskiej twórczości ludowej.

Kansas Franka Bauma to smutne i opuszczone miejsce przepełnione szarością, w którym nawet trawa pozbawiona jest swojej naturalnej barwy. Kolor szary ma tutaj szczególne znaczenie, gdyż nie tylko przyroda traci swoje piękno, ale to samo dzieje się także z wytworem pracy człowieka. Chociaż dom wydaje się barwny i piękny, to i tak jest przesądzone, że prędko wyblaknie. Nawet sami ludzie nie potrafią w tych warunkach uniknąć takiego losu, co potwierdza wygląd Ciotki Em: „The sun and wind had changed her, too. They had taken the sparkle from her eyes and left them a sober gray; they had taken the red from her cheeks and lips, and they were gray also"23. Dla Elli Kansas jest czymś więcej niż wyłącznie domem - to jej ojczyzna. Różnica ta zostaje dobitnie zaznaczona przez słowa, jakimi obie protagonistki opisują miejsce, z którego pochodzą. Gdy w rozdziale dziesiątym strażnik bramy prosi Dorothy, żeby powiedziała mu, gdzie znajduje się Kansas, odpowiada ona następująco: „I don't know, but it is my home, and I'm sure it's somewhere" ${ }^{24}$ [wyróżn. - M.K]. W radzieckiej wersji na to samo pytanie Elli odpowiada w sposób na pozór identyczny, lecz różniący się jedynym kluczowym detalem: „Я не знаю, - печально отвечала Элли. - Но это моя родина, и она где-нибудь да есть" 25 [wyróżn. - M.K.]. Maria Lomaka akcentuje różnice znaczeniowe między słowami „home” а „родина”. O ile w języku angielskim podstawowe znaczenie "home” oznacza po prostu dom, o tyle „родина” odnosi się już do ojczyzny, czyli przestrzeni istotnej dla całego narodu. Pragnienie powrotu do Kansas to u Elli chęć powrotu nie tylko do miejsca, w którym się mieszka, ale przede wszystkim do miejsca,

${ }^{21}$ Tamże, s. 188: „W wersji amerykańskiego pisarza Totoszka jest niemy. Wydawało mi się jednak, że w czarodziejskiej krainie, gdzie rozmawiają nie tylko ptaki i zwierzęta, ale nawet ludzie z żelaza i słomy, wierny Totoszka również powinien przemówić. I w mojej wersji przemówił”.

22 W. Propp, Morfologia bajki, tłum. W. Wojtyga-Zagórska, Warszawa 1976, s. 150.

${ }^{23}$ F.L. Baum, The Wizard of $\mathrm{Oz}$, dz. cyt., s. 8.

${ }^{24}$ Tamże, s. 62.

25 A. Wołkow, Wotszebnik Izumrudnogo goroda, dz. cyt., s. 53. 
z którym jest się związanym duchowo ${ }^{26}$. Nie tylko jednak Elli używa słowa „родина” zamiast bardziej podobnych semantycznie „жилище” сzу „дом”. Słowem „родина” posługuje się też narrator, opisując szerokie stepy Kansas: „Канзас был родиной Элли”27. Lawrence Venuti zauważa, iż domestykacja w tłumaczeniu objawia się przez swoistą redukcję tekstu do wartości typowych dla kultury docelowej ${ }^{28}$. Aleksander Wołkow dokonał w tłumaczeniu książki również innej korekty, nie ograniczając się jedynie do kwestii kolektywistycznej moralności, zamieniając oryginalny cyklon na bardziej prawdopodobny w tej szerokości geograficznej huragan. Posłużył się także podobnym zabiegiem, zmieniając obecne u Bauma prerie na stepy, bardziej typowe dla krajów rosyjskich. Fraza „bring the author back Home”, za pomocą której Venuti definiuję metodę udomowienia ${ }^{29}$, wyraźnie znajduje odniesienie w przekładzie Wołkowa. Pobrzmiewają tutaj też echa Manipulation School, dla której przedstawicieli proces tłumaczenia interlingwialnego będzie zawsze tożsamy ze swoistym przepisaniem (ang. „rewriting”) tekstu oryginalnego, co w skrajnych wypadkach może mieć zabarwienie ideologiczne ${ }^{30}$.

Dalsze rozbieżności w tłumaczeniu książki wynikają również z wcześniej zasygnalizowanego przywiązania większej wagi do kolektywu i pracy zespołowej dla osiągnięcia danego celu. Katerina Clark, przywołując metaforę maszyny, pisze, że sama w sobie nie jest ona wartościowa, gdyż może działać jedynie wtedy, gdy wszystkie jej trybiki pracują jednocześnie ${ }^{31}$. Podobnie jest z działaniami bohaterów adaptacji Wołkowa. Występuje tu motyw współzależności i zgodnej pracy dla wspólnego dobra. U Bauma wyraźnie zaś rezonuje model typowego dla kultury Zachodu „ja” niezależnego. W społeczeństwie, w którym indywidualność odgrywa dużą rolę, najważniejsze jest potwierdzanie wypracowanej już jaźni, silne akcentowanie swojej niezależności, a także współzawodnictwo $\mathrm{z}$ innymi ${ }^{32}$. Motyw współdziałania, według Brunona Bettelheima element służący osiągnięciu przez dziecko wyższej fazy rozwojowej ${ }^{33}$, przeplata się u Bauma z potrzebą zaznaczenia samodzielności, którą Wołkow z kolei minimalizuje. Gdy Dobra Czarownica z Północy tłumaczy Dorothy, co może zrobić, żeby wrócić do domu, nie są jej stawiane żadne dodatkowe wa-

${ }^{26}$ M. Lomaka, Totoshka, We're Not in Kansas Anymore: Translating American-Soviet Cold War Tension through the Wonderful Wizard of $\mathrm{Oz}$, Columbia 2013, s. 22, http://history.columbia. edu/wp-content/uploads/sites/20/2017/07/Maria-Lomaka.pdf, dostęp: 15.08.2017.

27 A. Wołkow, Wotszebnik Izumrudnogo goroda, dz. cyt., s. 4.

${ }^{28}$ L. Venuti, The Translator's Invisibility: A History of Translation Second Edition, London 2008, s. 15.

${ }^{29}$ Tamże.

30 A. Dukāte, Translation, Manipulation, and Interpreting, Frankfurt am Main 2009, s. 123.

${ }^{31}$ K. Clark, dz. cyt., s. 117.

32 K. Oatley, J.M. Jenkins, Zrozumieć emocje, tłum. J. Radzicki, J. Suchecki, Warszawa 2003, s. 44.

${ }^{33}$ B. Bettelheim, Cudowne i pożyteczne: znaczenie i doniostość baśni, tłum. D. Danek, „Teksty" 1980 , nr 1, s. 185. 
runki, wszystko zależy od niej samej i dziewczynka nie musi się oglądać na innych. Jest zdana na siebie, gdyż Czarownica daje jej do zrozumienia, że mimo iż wspiera ją i wierzy w powodzenie wyprawy, to Dorothy musi sama się udać przed oblicze Czarnoksiężnika. Zgoła odmiennie prezentuje się ta sytuacja u Aleksandra Wołkowa:

Великий волшебник Гудвин вернет домой маленькую девочку, занесенную в его страну ураганом, если она поможет трем существам добиться исполнения их самых заветных желаний ${ }^{34}$.

Tutaj dziewczynka musi pomóc trzem istotom w spełnieniu ich najskrytszych marzeń; tylko wtedy wielki Czarodziej Goodwin zechce pomóc Elli. Dzieje się to jeszcze przed spotkaniem Drwala, Lwa i Straszydła. Od samego początku bohaterka konfrontowana jest z faktem, że jej działania na nic się nie zdadzą, jeśli nie stanie się częścią wspólnoty, nawet nie wiedząc, kto będzie wchodził w jej skład. Wydaje się, że liczne odniesienia do roli kolektywu są u Wołkowa celowym zabiegiem, który wymusza pewną interpretację. André Lefevere przez pojęcie refrakcji definiuje adaptacje polegające na dostosowaniu elementów kultury wyjściowej do realiów kultury docelowej. Autor jest zdania, iż są one „dokonywane z zamysłem wywarcia wpływu na sposób, w jaki będą czytane" ${ }^{35}$. Zmieniając oryginalny zamysł Bauma, Wołkow wzbudza u radzieckiego odbiorcy przekonanie, iż w powieści Amerykanina nacisk położony zostaje na wartości typowe dla mieszkańców Kraju Rad. Jednocześnie należy zwrócić uwagę na symbolikę liczby trzy, która często pojawia się w tekstach folklorystycznych, między innymi jako intensyfikująca siłę słów oraz czynów ${ }^{36}$. Propp zauważa także, że liczba bohaterów stanowi ważny element $\mathrm{w}$ świecie przedstawionym bajki, a trójka jest w tym aspekcie jedną z najczęstszych kombinacji ${ }^{37}$.

Elli i Dorothy różnią się od siebie w wielu aspektach; inne środowisko życiowe to tylko jedna z części składowych tego zaskakującego kontrastu. Elli jawi się czytelnikowi jako postać odczuwająca o wiele więcej strachu niż jej amerykański pierwowzór. Ujawnia się to już na początku książki, między innymi przy pierwszym spotkaniu ze Strachem:

${ }^{34}$ A. Wołkow, Wotszebnik Izumrudnogo goroda, dz. cyt. (1963), s. 22: „Potężny czarodziej Goodwin odeśle do domu dziewczynkę, którą do jego krainy przywiał huragan, jeśli pomoże ona trzem istotom w spełnieniu ich najgłębszych marzeń".

${ }_{35}$ A. Lefevere, Ogórki Matki Courage, tłum. A. Sadza [w:] Wspótczesne teorie przektadu. Antologia, red. P. Bukowski, M. Heydel, Kraków 2009, s. 227.

${ }_{36}$ M. Wójtowicz, Semantyka wybranych liczb w kulturze ludowej mieszkańców wsi, „Studia Wschodniosłowiańskie" 2013, t. 13, s. 361-374.

37 W. Propp, dz. cyt., s. 52. 
She thought she must have been mistaken at first, for none of the scarecrows in Kansas ever wink; but presently the figure nodded its head to her in a friendly way. Then she climbed down from the fence and walked up to it, while Toto ran around the pole and barked.

Good day - said the Scarecrow, in a rather husky voice.

Did you speak? - asked the girl, in wonder ${ }^{38}$.

Она решила, что ей почудилось: ведь чучела никогда не мигают в Канзасе. Но фигура закивала головой с самым дружеским видом. Элли испугалась, а храбрый Тотошка с лаем набросился на изгородь, за которой был шест с чучелом ${ }^{39}$.

Frank Baum portretuje Dorothy jako rezolutną dziewczynkę, która nie tylko nie boi się niespodziewanego, a nawet podchodzi z ciekawością do Stracha. Elli zaś przestraszyła się samego widoku ruszającej się kukły i zbliżyła się do niej tylko dzięki obecności odważnego Totoszki.

Walery Bielanin, współczesny lingwista i psycholog, pokazuje jeszcze inne różnice w radzieckiej wersji Czarnoksiężnika z Krainy Oz. Rosyjski badacz zwraca bowiem szczególną uwagę na specyficzne elementy leksykalne, które w jego mniemaniu w wersji radzieckiej implikują smutek, strach czy przygnębienie, a których nie ma lub występują znacznie rzadziej w amerykańskim oryginale. Wymienia on sześć typów tekstów literackich: smutne, ciemne, jasne, wesołe, złożone i piękne ${ }^{40}$. W interpretacji Bielanina wersja Wołkowa zdaje się mieć dominantę ${ }^{41}$ ciemną, podczas gdy oryginał klasyfikowany jest jako tekst wesoły ${ }^{42}$. Samą dominantę emocjonalno-znaczeniową badacz definiuje jako „system kognitywnych i emotywnych reprezentacji umysłowych autora (...), operujący na wszystkich poziomach: leksykalnym, syntaktycznym, morfologicznym i stylistycznym" ${ }^{43}$ [tłum. - M.K.]. Bielanin zwraca uwagę na cechy typowe dla tekstów o ciemnej dominancie znaczeniowo-symbolicznej, które obecne są wyłącznie w książce Aleksandra Wołkowa. Pierwszą tego oznaką jest dodany przez Wołkowa rozdział zatytułowany Powódź (ros. Наводнение). W tym rozdziale odpoczywających na wyspie bohaterów zaskakuje burza. Fakt

38 F.L. Baum, The Wizard of $\mathrm{Oz}$, dz. cyt., s. 22.

39 „Doszła do wniosku, że się jej [Elli - M.K.] przywidziało; przecież kukły nie mrugają w Kansas. Postać kiwnęła jednak głową, uśmiechając się przyjaźnie. Elli przestraszyła się, a dzielny Totoszka, ujadając, rzucił się na ogrodzenie, za którym była wbita na pal kukła”. A. Wołkow, Wotszebnik Izumrudnogo goroda, dz. cyt., s. 13.

40 W.P. Bielanin, Psichotogiczeskoje litieraturowiedienije. Tiekst kak otrażenije wnutriennich mirow awtora i czitatiela, Moskwa 2006, s. 242-243.

41 Nie należy tutaj utożsamiać Bielaninowskiego pojęcia dominanty z proponowaną przez Stanisława Barańczaka w Ocalone w ttumaczeniu dominantą semantyczną.

42 W.P. Bielanin, dz. cyt., s. 295.

43 Tamże, s. 298. 
ten ma olbrzymie znaczenie dla dwójki bohaterów - Straszydła i Drwala. Dla nich jakikolwiek kontakt z wodą okazałby się zabójczy, o czym przytomnie wspomina Drwal, na co Straszydło reaguje histerycznym krzykiem ${ }^{44}$.

Ostatecznie piątce bohaterów udaje się wyjść zwycięsko z konfrontacji z żywiołem, mimo iż nie przychodzi im to z łatwością; Lew, Elli i Totoszka „czekali trzy dni na brzegu, aż woda opadnie” ${ }^{45}$, a sam Drwal zardzewiał i nie mógł się poruszyć. To samo dzieje się też ze Straszydłem, który zmókł i zawisł na krzakach w „przedziwnej pozie” (ros. „в причудливой позе”) ${ }^{46}$. Jednak dzięki współpracy wszystkich bohaterów udaje im się pokonać również i tę przeszkodę. Co więcej, u Wołkowa to właśnie bohaterskie starcie z powodzią jest dla Tchórzliwego Lwa ostatecznym testem przed walką z olbrzymim pająkiem, dzięki pokonaniu którego Lew ostatecznie zyskuje tytuł Króla Zwierząt. Wprawdzie motyw zmagań człowieka z żywiołem jest mocno zakorzeniony w literaturze światowej, jednak obraz kolektywu zdolnego do podporządkowania natury ludzkiej woli stanowił ważny element konstruowania obrazu człowieka sowieckiego jako niezwyciężonego herosa ${ }^{47}$, zatem Wołkow nieprzypadkowo go wprowadza. Kolejnym z dwóch dodanych przez Wołkowa rozdziałów jest historia porwania głównej bohaterki przez Ludojada. Już samo miejsce, w którym rezyduje ich przeciwnik, napawa głównych bohaterów przerażeniem: „Замок Людоеда стоял на холме. Его окружала высокая стена, на которую не вскарабкалась бы и кошка. Перед стеной был ров, наполненный водой" ${ }^{48}$. Ponownie pojawia się motyw wody, tym razem pod postacią fosy odgradzającej dwójkę bohaterów od porwanej towarzyszki. I nawet jeśli misja ratunkowa ostatecznie kończy się dobrze, to rezultaty spotkania z Ludojadem są długofalowe - w rozdziale Spotkanie z Tchórzliwym Lwem Elli śni się „niepokojący” (ros. „тревожен”) koszmar, w którym jest związana i krojona nożem przez Ludożercę zabitego przez Żelaznego Drwala.

Pod wieloma względami rozdziały Наводнение і Элли в плену у Людоeda są do siebie podobne. W obu z nich niektórzy bohaterowie znajdują się w śmiertelnym niebezpieczeństwie i muszą być uratowani przez swoich współtowarzyszy, którzy w tym celu wykazują się niemal nadludzką determinacją i odwagą. Bez ich pomocy pozostali członkowie drużyny nie potrafią bowiem nic zrobić, co ukazuje wyższość działania w kolektywie nad czynami jednostki. Idąc tym tropem, bohaterowie występujący w roli ratujących sami odczuwają strach i początkowo boją się podjąć działanie.

${ }^{44}$ A. Wołkow, Wotszebnik Izumrudnogo goroda, dz. cyt., s. 107.

45 Tamże, s. 111.

46 Tamże, s. 112.

47 K. Clark, dz. cyt., s. 103.

48 „Zamek Ludojada stał na wzgórzu. Okrążał go wysoki mur, na który nie wdrapałby się żaden kot. Fasadę twierdzy otaczała fosa wypełniona wodą”. A. Wołkow, Wotszebnik Izumrudnogo goroda, dz. cyt., s. 26. 
Pojawiają się też łzy. W opisywanym fragmencie, gdy Elli dostaje się do niewoli Ludożercy, płacze Żelazny Drwal, a w czasie powodzi, gdy woda wzbiera - sama Elli wybucha płaczem. W obu wypadkach szlochające postaci uspokajają przyjaciele, odpowiednio Straszydło i Tchórzliwy Lew:

- Надо спасать Элли! - закричал Страшила. - Да, да! - горячо подхватил Железный Дровосек. - Элли спасла нас, а мы должны отбить ее у Людоеда. Иначе я умру с горя... - И слезы покатились по щекам Железного Дровосека [wyróżn. - M.K. $]^{49}$.

Шапка взлетела, белой звездочкой блеснула во мраке и исчезла. Элли зарыдала, но громкий раскат, раздавшийся над головами путников, заглушил ее рыдания. - Не плачь, Элли! - заревел ей на ухо Лев ${ }^{50}$.

W wyróżnionym związku frazeologicznym użytym przez Żelaznego Drwala obecny jest również motyw śmierci („умереть с горя” - umrzeć z rozpaczy). Co więcej, w tych rozdziałach często pojawiają się takie słowa, jak „страшная” сzy „ужасно”, które są semantycznymi komponentami słowa „strach” ${ }^{1}$. Ukazuje to budzącą grozę naturę wersji Wołkowa, który adaptując tekst, stara się dostosować go do oczekiwań czytelnika, zaznajomionego z mroczną twórczością braci Grimm oraz Aleksandra Afansajewa ${ }^{52}$. Porwanie Elli można też interpretować przez pryzmat jednej z kolejnych funkcji bajki, jaką jest poddanie bohatera próbie ${ }^{53}$.

Walery Bielanin twierdzi, że trudności w mówieniu są również cechą tekstów o ciemnym zabarwieniu. Strach na wróble to postać, która u Aleksandra Wołkowa notorycznie jąka się, gubi sylaby i często w miejsce normalnych słów używa onomatopei:

И - крак! крак! - села волшебнице на голову [wyróżn. - M.К.] ${ }^{54}$.

Ах, какая радость! Я снова, снова, снова с Элли! ${ }^{55}$

49 „Musimy uratować Elli! - krzykną Straszydło. Tak, tak! - ochoczo dołączył do niego Żelazny Drwal - Elli wcześniej uratowała nas, musimy odbić ją z rąk Ludojada. W przeciwnym razie umrę z rozpaczy... Wtem po policzkach Żelaznego Drwala popłynęły łzy”. Tamże, s. 25.

50 "Czapka wzleciała do góry, biała gwiazdka błysnęła w mroku i zniknęła. Elli zaszlochała, ale głośny grzmot, który rozległ się nad głowami, zagłuszył jej łkanie. Nie płacz, Elli - zaryczał jej do ucha Lew". Tamże, s. 108.

51 W.P. Bielanin, dz. cyt., s. 294.

52 J. Zipes, Grimm Legacies: The Magic Spell of the Grimms' Folk and Fairy Tales, Harvard 2014, s. 1-2, 28.

53 W. Propp, dz. cyt., s. 86.

54 „I - Krak! Krak! - usiadła wiedźmie na głowie”. A. Wołkow, Wotszebnik Izumrudnogo goroda, dz. cyt., s. 23.

55 „Ach, jaka radość! Ja znowu, znowu, znowu z Elli!”. Tamże, s. 113. 
Krasilnikova zwraca uwagę, że jest to charakterystyczne wyłącznie dla tekstu Wołkowa, bowiem podobne zabiegi nie zostały zastosowane ani w wierniejszym oryginałowi przekładzie Siergieja Biełowa z 1992 roku (Удивительный волиебник страны Оз), ani w tłumaczeniu zbiorowym wydanym dwadzieścia lat później (Великий Чародей страны Оз ${ }^{56}$. Co znamienne, te trudności objawiają się nie tylko w momentach trwogi czy przerażenia, ale także radości i szczęścia. Oznacza to, że jest to reakcja Straszydła nawet na pozytywne zdarzenia. Należy podkreślić, że podobne defekty w mowie nie występują w oryginale. Są one wyłącznie elementem dodanym przez Aleksandra Wołkowa. Emocjonalność i porywczość Straszydła zostaje zatem w radzieckiej wersji znacznie uwydatniona w porównaniu z pierwowzorem.

Nagłe zmiany rozmiarów również składają się na ciemne zabarwienie tekstu literackiego ${ }^{57}$. W tekście Wołkowa pojawiają się sytuacje, w których postacie z niewytłumaczalnych przyczyn manipulują swoim kształtem, w mgnieniu oka kilkukrotnie powiększając przedmioty lub samemu kurcząc się do rozmiarów naparstka:

As for the little old woman, she took off her cap and balanced the point on the end of her nose, while she counted "One, two, three" in a solemn voice. At once the cap changed to a slate, on which was written in big, white chalk marks: "LET DOROTHY GO TO THE CITY OF EMERALDS" ${ }^{\prime 8}$.

Виллина вынула из складок одежды крошечную книжечку величиной с наперсток. Волшебница подула на нее, и на глазах удивленной и испуганной Элли книга начала расти, расти и превратилась в громадный том.

Он был так тяжел, что старушка положила его на большой камень ${ }^{59}$.

U Bauma Dobra Wiedźma z Północy rzuca zaklęcie, po czym na głazie pojawia się napis. Tutaj rozmiar przedmiotów i postaci pozostaje niezmienny od początku do końca. U Wołkowa zaś książeczka wielkości naparstka zmienia się do tego stopnia, że Wiedźma musi położyć ją na kamieniu, gdyż nie może jej utrzymać. Wszystko rozgrywa się w mgnieniu oka, co wywołuje u Elli trwogę i zdziwienie.

Виллина наклонилась к огромной книге, и та тотчас сжалась до размеров напёрстка, и исчезла в складках мантии. Налетел вихрь, стало темно,

56 W.P. Krasilnikova, dz. cyt.

57 W.P. Bielanin, dz. cyt., s. 102.

58 F.L. Baum, The Wizard of $O z$, dz. cyt., s. 16.

59 „Willina wyjęła z fałd szaty malusieńką książeczkę wielkości naparstka. Czarownica zaczęła na nią dmuchać, po czym w oczach zadziwionej i przestraszonej Elli książka zaczęła rosnąć, rosnąć, aż w końcu przeobraziła się w olbrzymi tom. Był tak ciężki, że staruszka musiała położyć go na dużym kamieniu”. A. Wołkow, Wotszebnik Izumrudnogo goroda, dz. cyt. (1963), s. 21. 
И когда мрак рассеялся, Виллины уже не было: волшебница исчезла. Элли и Жевуны задрожали от страха, и бубенчики на шляпах маленьких людей зазвенели сами собой ${ }^{60}$.

Żegnając się z Elli, Willina wpierw zmniejsza „ogromną” książkę, a następnie sama prędko znika, zostawiając główną bohaterkę i towarzyszących jej Manczkinów ${ }^{61}$ drżących ze strachu.

Przekład Aleksandra Wołkowa - jako zaburzający równowagę między ekwiwalencją tekstu wyjściowego i docelowego ${ }^{62}$ - jest niewątpliwie nacechowany elementami kulturowymi dużo bardziej czytelnymi i zrozumiałymi dla radzieckiego czytelnika wychowanego na innej literaturze niż jego amerykański rówieśnik z początku XX wieku. Intencją Wołkowa było przede wszystkim pokazanie dzieciom innego, fantastycznego świata, w którym ostatecznie zwycięża dobro. Jak pisze sam autor w posłowiu do późniejszych wydań: „opowieść uczy tego, że każde kłamstwo, każde oszustwo koniec końców wychodzi na jaw" "63. Prawdą jest, iż autorzy powieści socrealistycznych kładli nacisk na funkcję wychowawczą swoich dzieł, co miało pomóc w formowaniu człowieka nowych czasów ${ }^{64}$. W wypadku bajki dochodzi jednak do przeplatania się treści dydaktycznych swoistych w ogóle dla bajki jako gatunku oraz tych akcentujących bieżące zadania ideologiczne w ZSRR lat trzydziestych XX wieku. Aleksander Wołkow nie zmienia wszak głównego przekazu tekstu Bauma; w Czarodzieju Szmaragdowego Miasta wciąż wyraźnie rezonują motywy uniwersalne dla bajki: zwycięstwo dobra nad złem czy wartość przyjaźni ${ }^{65}$. Częściowa sowietyzacja $C z a r n o k s i e ̨ z n i k a ~ z ~ K r a i n y ~ O z$ wynika zatem głównie z potrzeby uczynienia pierwotnego kontekstu powieści Bauma zrozumiałym dla odbiorcy dziecięcego w ZSRR oraz przesunięcia punktu ciężkości na wartości i postawy szczególnie aktualne dla radzieckiego społeczeństwa. Chociaż Lefevere twierdzi, że autorzy tłumaczeniowych refrakcji często przemycają do przekładanych utworów elementy ideologiczne, skrzywiające intencje auto$\mathrm{ra}^{66}$, to nadużyciem byłoby jednak nadanie Aleksandrowi Wołkowowi łatki

${ }^{60}$ „Willina pochyliła się nad ogromną książką i ta natychmiast skurczyła się do rozmiarów naparstka, i zniknęła w fałdach płaszcza. Nadleciał wicher, zapadła ciemność i kiedy mrok rozproszył się, Williny już nie było: czarownica zniknęła. Elli i Żewuny zatrzęśli się ze strachu, a dzwoneczki na kapeluszach małych ludzi zaczęły same dzwonić”. Tamże, s. 23.

${ }^{61}$ Manczkinowie (ang. Munchkins) to jeden z ludów mieszkających w Krainie Oz. Wołkow przetłumaczył ich nazwę jako Żewuny (ros. Жевуны), od rosyjskiego słowa „жевать” („żuć).

${ }^{62}$ E. Manasterska-Wiącek, Adaptacja i egzotyzacja w przekazie nazw wtasnych (na materiale poezji dziecięcej Juliana Tuwima i Jana Brzechwy), „Acta Polono-Ruthenica” 2006, t. 11, s. 342.

${ }^{63}$ A. Wołkow, Wotszebnik Izumrudnogo goroda, dz. cyt. (1963), s. 187.

${ }^{64}$ P. Fast, Poetyka rosyjskiej powieści produkcyjnej (1929-1941), Katowice 1981, s. 23.

${ }_{65}$ G. Suciu, A Comparative Analysis of Fairy Tale Heroes and Heroines Through Gender Lens, The Proceedings of the „European Integration - Between Tradition and Modernity” Congress”, t. 6, Tirgu-Mures 2015, s. 311.

${ }_{66}$ A. Lefevere, dz. cyt., s. 240. 
propagandzisty, zwłaszcza że tłumacz czerpał również z motywów uniwersalnych dla literatury rosyjskojęzycznej.

\section{Bibliografia}

Baker M., Saldanha G., Routledge Encyclopedia of Translation Studies: Second Edition, London 2009.

Balina M., Creativity through Restraint: The Beginnings of Soviet Children's Literature [w:] Russian Children's Literature and Culture, red. M. Balina, L. Rudova, New York 2008.

Baranow W.I., Orudije poznanija i bor'by. O socyalisticzeskom realizmie kak mietodie chudożestwiennogo myszlenija, Moskwa 1978.

Baum F.L., Czarodziej z Krainy Oz, tłum. M. Pawlik-Leniarska, Warszawa 1993.

Baum F.L., The Wizard of $\mathrm{Oz}$, London 1993.

Bettelheim B., Cudowne i pożyteczne: znaczenie i doniostość baśni, tłum. D. Danek, "Teksty” 1980, nr 1.

Bielanin W.P., Psichotogiczeskoje litieraturowiedienije. Tiekst kak otrażenije wnutriennich mirow awtora i czitatiela, Moskwa 2006.

Branson R., Carving the Perfect Citizen: The Adventures of Italian Pinocchio in the Soviet Union and the United States, „Honors Projects” 2014, http://digitalcommons.iwu.edu/cgi/viewcontent.cgi?article=1017\&context=intstu_honproj, dostęp: 15.08.2017.

Clark K., The Soviet Novel: History as Ritual, Chicago 1985.

Dukāte A., Translation, Manipulation, and Interpreting, Frankfurt am Main 2009.

Fast P., Poetyka rosyjskiej powieści produkcyjnej (1929-1941), Katowice 1981.

Haber E., Is Magic Land Oz? A.M. Volkov and the Question of Originality, „Detskiechtenija” 2014, nr 6 (2).

Jarosiński Z., Literatura lat 1945-1975, Warszawa 1996.

Krasilnikova W.P., Psicholingwisticzeskij analiz siemanticzeskich transformacyj pri pieriewodie i litieraturnom pierieskazie chudożestwiennogo tieksta, http://individual. utoronto.ca/psyling/library/tran/krasil_avtoreferat.htm, dostęp: 31.03.2017.

Lefevere A., Ogórki Matki Courage, tłum. A. Sadza [w:] Wspótczesne teorie przektadu. Antologia, red. P. Bukowski, M. Heydel, Kraków 2009.

Litwinow J., Wczesna rosyjska proza radziecka i Rewolucja Październikowa, „Studia Rossica Posnaniensia” 1979, t. 11.

Lomaka M., Totoshka, We're Not in Kansas Anymore: Translating American-Soviet Cold War Tension through the Wonderful Wizard of Oz, Columbia 2013, http:// history.columbia.edu/wp-content/uploads/sites/20/2017/07/Maria-Lomaka. pdf, dostęp: 15.08.2017.

Manasterska-Wiącek E., Adaptacja i egzotyzacja w przekazie nazw wtasnych (na materiale poezji dziecięcej Juliana Tuwima i Jana Brzechwy), „Acta Polono-Ruthenica” 2006, t. 11. 
Oatley K., Jenkins J.M., Zrozumieć emocje, tłum. J. Radzicki, J. Suchecki, Warszawa 2003.

Propp W., Morfologia bajki, tłum. W. Wojtyga-Zagórska, Warszawa 1976.

Rogers K., L. Frank Baum, Creator of Oz: A Biography, New York 2002.

Suciu G., A Comparative Analysis of Fairy Tale Heroes and Heroines through Gender Lens, The Proceedings of the „European Integration - Between Tradition and Modernity" Congress, t. 6, Tirgu-Mures 2015.

Venuti L., The Translator's Invisibility: A History of Translation Second Edition, London 2008.

Vid N., Teaching Russian through Translations, „Informatologia” 2014, t. 47, nr 1.

Vid N., Use of Domesticated and Foreignized Method in the Soviet School of Translation, „ELOPE” 2007, t. 4, nr 1-2 (red. S. Komar, U. Mozetic).

Wołkow A., Wotszebnik Izumrudnogo goroda, Moskwa 1939.

Wołkow A., Wotszebnik Izumrudnogo goroda, Moskwa 1963.

Wójtowicz M., Semantyka wybranych liczb w kulturze ludowej mieszkańców wsi, „Studia Wschodniosłowiańskie” 2013, t. 13.

Zipes J., Grimm Legacies: The Magic Spell of the Grimms' Folk and Fairy Tales, Harvard 2014. 